International Journal of Public Finance
E-ISSN: $2548-0499 \quad$ DOI: $10.30927 /$ ijpf.327776
Vol./Cilt: 2 | Issue/Sayı: 2 | (2017), pp. $196-219$
journal homepage: http://dergipark.gov.tr/ijpf

\title{
Vergi Adaleti Açısından Türkiye'de Ücret Gelirlerinin Vergilendirilmesi
}

\author{
Taxation of Wage Incomes in Terms of Tax Justice in Turkey
}

\author{
Hakan BAY ${ }^{1} \quad$ Ahmet iNNECi
}

\section{ARTICLE INFO}

Received: 11.07.2017

Received in revised

form: 27.11.2017

Accepted: 08.12.2017

Available online:

05.01.2018

\section{JEL classification:}

$\mathrm{H} 24, \mathrm{~K} 34, \mathrm{~K} 40$

\section{Keywords:}

Tax Justice, Wage

Income, Taxation,

Withholding

Procedure

\begin{abstract}
A B S T R A C T
While wage income is taxed in the Turkish tax system, it is observed that some taxpayer groups have been taxed in different procedures and thus a number of practices have been observed that have damaged the tax justice. Since the wage income is generally taxed by withholding, this situation causes some problems in terms of tax justice. The fact that the application of the annual declaration is limited in the taxation of the wage income makes the wage earners disadvantageous to those who earn income and revenues from the other income elements in terms of the deductions that can be utilized in reaching the net income. In addition, as a requirement of the separation principle, the wage incomes have to be taxed at a lower rate than capital gains.

In this study, the regulations regarding the taxation of the wage incomes in the Turkish tax system will be examined and applications contrary to the tax justice will be presented and the necessary suggestions will be made.
\end{abstract}

\section{MAKALE BILGISi}

Alındı: 11.07.2017

Gözden geçirilmiş

alındı: 27.11.2017

Kabul: 08.12.2017

Yayın: 05.01.2018

\section{JEL Kodu:}

$\mathrm{H} 24, \mathrm{~K} 34, \mathrm{~K} 40$

\section{Anahtar Kelimeler: \\ Vergi Adaleti, Ücret \\ Geliri, Vergilendirme,}

\section{Ö Z E T}

Türk vergi sisteminde ücret gelirleri vergilendirilirken bazı mükellef gruplarının farklı usullerde vergilendirildiği ve bu sebepten dolayı vergi adaletini zedeleyen bir takım uygulamalar ortaya çıktığı gözlemlenmektedir. Ücret gelirlerinin vergilendirilmesi genel olarak stopaj (kaynakta kesinti) yoluyla yapıldığından, bu durumun da vergi adaleti açısından bir takım sorunlara neden olduğu görülmektedir. Ücret gelirlerinin vergilendirilmesinde yıllık beyanın sınırlı uygulama alanı bulması, safi gelire ulaşmada yararlanılabilecek indirimler açısından ücretlileri diğer gelir unsurlarından kazanç ve irat elde edenler karşısında dezavantajlı hale getirmektedir. Ayrıca ayırma prensibinin bir gereği olarak ücretin sermaye kazançlarına nazaran daha düşük oranda vergilendirilmesi gerekmektedir.

1 Araş. Gör. Dr., Dokuz Eylül Üniversitesi, iliBF, Maliye Bölümü, Mali Hukuk A.D., hakan.bay@deu.edu.tr

2 Araş. Gör., Dokuz Eylül Üniversitesi, iïBF, Maliye Bölümü, Mali Hukuk A.D., ahmet.inneci@deu.edu.tr 
Stopaj Usulü

$\mathrm{Bu}$ çalışmada Türk vergi sisteminde ücret gelirlerinin vergilendirilmesine ilişkin yer alan düzenlemeler incelenecek ve vergi adaletine ters düşen uygulamalar ortaya konularak olması gerekene yönelik öneriler getirilecektir.

\section{Giriş}

Vergi adaleti maliye literatüründe uzun yıllardır tartışılmakta olan ve sınırları tam olarak belirlenemeyen bir kavramdır. Vergi adaleti zamana, mekana ve ülke yapısına göre farklılık gösterebilmektedir. Vergi adaletinin özünü, aynı mali durumda olanların aynı, farklı mali durumda olanların ise farklı şekilde vergilendirilmesi oluşturur. Maliye literatüründe gelir vergisinin sübjektif niteliği, artan oranlı tarifesi, en az geçim indirimi gibi uygulamalar nedeniyle en adil vergi olduğu konusunda görüş birliği hakimdir. Ancak uygulamaya bakıldığında gelir unsurlarının farklı vergilendirme usullerine tabi olmaları nedeniyle vergi adaleti açısından birtakım sorunların ortaya çıktığı görülmektedir. Özellikle ücret gelirlerinin vergilendirilmesinde tüm mükellef grupları için tek bir usulün belirlenmesi, mükellef sayısının ve mükellef grubunun birden fazla olması sebebiyle oldukça zordur. Tek bir usulün belirlenememesi de vergilendirmede kimi ücretlilerin adil olmayan vergilendirme işlemlerine tabi olmalarına neden olmaktadır.

Çalışmada, ücret gelirlerinin vergilendirilmesinde "vergilemede adalet ilkesi"nin tesisi için var olan uygulamaların olumsuz yönlerinin giderilmesine yönelik öneriler getirilmektir. Bu amaçla vergi adaleti açısından ücretliler aleyhine sonuçlar doğuran matrahın tespiti, vergilendirme usulü, artan oranlı vergi tarifesi, muafiyet ve istisnalar gibi konular çalışmanın odak noktasını oluşturmaktadır.

\section{2. Ücret Kavramı ve Türk Vergi Sisteminde Ücret Gelirlerinin Vergilendirme Esasları}

\subsection{Genel Olarak Ücret Kavramı}

Iktisadi açıdan ücret, üretim faktörü olan emeğin bir karşılığıdır ve bu karşılık nakdi ya da ayni şekilde olabilir (Tosuner \& Arıkan, 2017: 99). Emek, üretime fikren ya da bedenen katılabilir. Bu nedenle emeğin üretime fikren ya da bedenen katılması karşılığında alınan bedele ücret denilmektedir (Şenyüz, 2007: 151). Ücret gerek kamu hukukunun gerekse özel hukukun farklı dallarında farklı anlamlara gelmek üzere kullanılabilen bir kavramdır. Nitekim 4857 sayılı İ̧ Kanunu"nun 32. maddesinde "Genel anlamda ücret bir kimseye bir iş karşılığında işveren veya üçüncü kişiler tarafından sağlanan ve para ile ödenen tutardır" şeklinde tanımlanmaktadır. Bunun yanında ücrete ilişkin genel bir düzenlemeye 6098 sayılı Türk Borçlar Kanunu"nun "Hizmet Sözleşmeleri" isimli Altıncı Bölüm'ünde yer verilmektedir. Kanun'un 393. maddesine göre "Hizmet sözleşmesi, iş̧̧inin işverene bağımlı olarak belirli veya belirli olmayan süreyle işgörmeyi ve işverenin de ona zamana veya yapılan işe göre ücret ödemeyi

3 RG: $25134-10 / 06 / 2003$

4 RG: $27836-04 / 02 / 2011$ 
üstlendiği sözleşmedir." Burada yapılan tanım özel hukuk esaslarına göre ortaya çıkan ücret ile ilgilidir (Erginay, 1995: 190).

\subsection{Vergi Hukuku Açısından Ücret Kavramı}

193 sayılı Gelir Vergisi Kanunu ${ }^{5}$ (G.V.K.)'nun 61. maddesinde ücretin tanımına yer verilmektedir. Bu maddeye göre ücret, işveren tabi ve belirli bir işyerine bağlı olarak çalışanlara hizmet karşılığı verilen para ve ayınlar ile sağlanan ve para ile temsil edilebilen menfaatlerdir. Bu tanımdan ücretin sadece nakit ödemeleri değil, her türlü ayın ödemesini ve para ile temsil edilen diğer menfaatleri de kapsadığı anlaşılmaktadır. Nitekim ilgili maddenin devamında ücretin ödenek, tazminat, kasa tazminatı (mali sorumluluk tazminatı), tahsisat, zam, avans, aidat, huzur hakkı, prim, ikramiye, gider karşıı̆̆ı veya başka adlar altında ödenmiş olması veya bir ortaklık münasebeti niteliğinde olmamak şartı ile kazancın belli bir yüzdesi şeklinde belirlenmesinin ücretin mahiyetini değiştirmeyeceği belirtilmiştir. Bunun yanında G.V.K.'nda yapılan ücret tanımı sadece özel hukuktan doğan ücretleri değil, kamu ya da idare hukukundan doğan memuriyet hizmetleri nedeniyle yapılan ödemeleri de kapsamaktadır (Erginay, 1995: 190).

G.V.K.'nda ücret tanımına açık bir şekilde yer verilmiş ve ücretin sınırları genel olarak belirlenmiş olmasına rağmen, uygulamada bazı ödemelerin ücret sayılıp sayılamayacağının tereddütlere neden olabilme ihtimaline karşı kanun koyucu bazı ödemelerin kesin olarak ücret niteliğinde olduğunu açıkça belirtmiştir ${ }^{6}$ (Bulutoğlu, 1976: 132).

G.V.K.'nun 61. maddesinde yapılan ücret tanımından yapılan ödemenin ücret olarak kabul edilebilmesi için birtakım unsurların gerekli olduğu anlaşılmaktadır. Buna göre işverene ve belirli bir işyerine bağlı olarak çalışılması, ödemenin hizmet karşılığı olarak yapılması ve ödemenin para, ayın veya para ile temsil edilebilen menfaat şeklinde olması gerekir.

5 RG: $10700-06 / 01 / 1961$

6 G.V.K.'nun 61. maddesine göre aşağıda yer alan ödemeler ücret olarak kabul edilecektir.

- Kanunla kurulan emekli sandıkları ile 506 sayılı Sosyal Sigortalar Kanunu’nun geçici 20. maddesinde belirtilen bankalar, sigorta ve reasürans şirketleri, ticaret odaları, sanayi odaları, borsalar veya bunların teşkil ettikleri birlikler personelinin malûllük, yaşlılık ve ölümlerinde yardım yapmak üzere kurulan sandıklar tarafından ödenen emekli, malûliyet, dul ve yetim aylıkları, (506 sayılı Sosyal Sigortalar Kanununun geçici 20. maddesinde belirtilen sandıklar tarafından ödenen aylıkların toplamı, en yüksek devlet memuruna çalışılan süreye bağıı olarak ödenen tutardan fazla ise aradaki fark ücret olarak vergiye tabi tutulur.)

- Evvelce yapılmış veya gelecekte yapılacak hizmetler karşılığında verilen para ve ayınlarla sağlanan diğer menfaatler,

- Türkiye Büyük Millet Meclisi, il genel meclisi ve belediye meclisi üyeleri ile özel kanunlarına veya idari kararlara göre kurulan daimî veya geçici bütün komisyonların üyelerine ve yukarıda sayılanlara benzeyen diğer kimselere bu sıfatları dolayısıyla ödenen veya sağlanan para, ayın ve menfaatler,

- Yönetim ve denetim kurulları başkanı ve üyeleriyle tasfiye memurlarına bu sıfatları dolayısıyla ödenen veya sağlanan para, ayın ve menfaatler,

- Bilirkişilere, resmî arabuluculara, eksperlere, spor hakemlerine ve her türlü yarışma jürisi üyelerine ödenen veya sağlanan para, ayın ve menfaatler,

- Sporculara transfer ücreti veya sair adlarla yapılan ödemeler ve sağlanan menfaatler. 
İşverene Tabi Olma: İşverenin kim olduğuna dair tanım G.V.K.'nun 62. maddesinde yapılmıştır. Buna göre hizmet erbabını işe alan, emir ve talimatları dahilinde çalıştıran gerçek ve tüzel kişilere işveren denilmektedir ${ }^{7}$. Yine aynı maddenin ikinci fıkrasında G.V.K.'nun 61. maddesinde sayılan ödemeleri yapanların da kanunda yazılı ödevleri yerine getirmek bakımından işveren hükmünde olduğu belirtilmiştir.

G.V.K.'nda yapılan ücret tanımında işverene tabi olma unsuruna yer verilmek suretiyle, ücretin bağımlı emeğin bir kazancı olduğunu, diğer bir deyişle hizmet akdinden doğduğu belirtilmektedir (Öncel vd., 2012: 287). İşverene tabi olma, hizmet erbabının işverenin belirlediği bir organizasyon içinde faaliyetini sürdürmesi, kendi nam ve hesabına değil işverenin nam ve hesabına çalışması anlamına gelir (Şenyüz, 2007: 152). Buradaki tabi olma fiili olabileceği gibi kanun, tüzük, yönetmelik veya sözleşmelerle de saptanmış olabilir (GiB, 2017a: 2).

Belirli Bir İşyerine Bağı Olma: 213 sayılı Vergi Usul Kanunu"nun 156. maddesi işyerini "Ticari, sınai, zirai ve mesleki faaliyette iş yeri; mağaza, yazıhane, idarehane, muayenehane, imalathane şube, depo, otel, kahvehane, eğlence ve spor yerleri, tarla, bağ, bahçe, çiftlik, hayvancılık tesisleri, dalyan ve voli mahalleri, madenler, taş ocakları, inşaat şantiyeleri, vapur büfeleri gibi ticari, sınai, zirai veya mesleki bir faaliyetin icrasına tahsis edilen veya bu faaliyetlerde kullanılan yerdir." şeklinde tanımlamaktadır. Kanunda yapılan tanımdan işyerinin bir mekân (yer) olduğu ve bu açıdan işyerinin hukuki olmaktan çok, fiili bir kavram olduğu anlaşılmaktadır (Tuncer, 2012: 196).

Hizmet erbabına yapılan ödemenin ücret olarak kabul edilebilmesi için hizmet erbabının yukarıdaki maddede tanımı verilen işyerine bağlı bir şekilde çalışması gerekmektedir. Buradaki bağııık maddi anlamda değil hukuki anlamda bir bağlılıktır ve bu nedenle hizmet erbabının işyerinde fiilen çalışması zorunlu değildir (Bulutoğlu, 1976: 131; Öncel vd., 2012: 287).

Ödemenin Hizmet Karşılığı Olarak Yapılması: Ücretin hizmet karşılığı olarak ödenmemesi halinde bu ödeme ücret olarak kabul edilemez. Bunun yanında yapılan ödemenin hizmet sunumundan önce veya sonra yapılması onun ücret olma niteliğini etkilemeyecektir (Tosuner \& Arıkan, 2017: 100).

Ödemenin Para, Ayın veya Para İle Temsil Edilebilen Menfaat Şeklinde Olması: Yapılan ödemenin ücret olarak kabul edilebilmesi için para, ayın veya para ile temsil edilebilen menfaat şeklinde yapılması gerekir. Ödemenin Türk Parası ya da döviz cinsinden yapılması onun ücret olma niteliğini değiştirmez. G.V.K.'nun 63. maddesine göre döviz cinsinden yapılan ödemeler ödeme gününün borsa rayiciyle Türk parasına çevrilir. Ödemenin ayın şeklinde yapılması halinde ayınlar, verildiği gün ve yerdeki ortalama perakende fiyatlarına göre; konut tedariki ve sair suretle sağlanan menfaatler ise, konutun emsal kirasına veya menfaatin emsal bedeline göre değerlenir.

\footnotetext{
7 İşverenin kim olduğuna dair diğer bir tanım da 4857 sayılı Iş Kanunu'nun 2. maddesinde yapıımıştır. Buna göre, iş̧̧ çalıştıran gerçek veya tüzel kişiye veya tüzel kişiliği olmayan kurum ve kuruluşlara işveren denilmektedir.

8 RG: $10703-10 / 01 / 1961$
} 


\section{3. Ücretlerde Elde Etme}

Gelir Vergisi açısından vergiyi doğuran olay ${ }^{9}$, gelirin elde edilmesidir (Bulutoğlu, 1976: 78). Bu nedenle gelirin ne zaman elde edilmiş sayılacağı, başka bir deyişle, vergiyi doğuran olayın ne zaman gerçekleşeceği vergilendirme açısından büyük bir öneme sahiptir (Kaneti, 1986/1987: 269-270). Çünkü vergi borcu ilişkisinde vergiyi doğuran olayın gerçekleştiği tarihte yürürlükte olan kanun hükümleri uygulama alanı bulacaktır. Bunun yanında uygulanacak oran, istisna ve muafiyetler, doğacak şekli ve maddi vergi ödevlerinin yerine getirilme zorunluluğu gibi hususlarda da vergiyi doğuran olay büyük bir öneme sahiptir (Öncel vd., 2012: 249-250).

G.V.K. genel düzenlemelerinde "elde etme" kavramına açık bir şekilde yer verilmemiş olsa da farklı kazanç ve irat türlerini düzenleyen ayrıntılı hükümlerde her bir kazanç ve irat bakımından vergiyi doğuran olayın belirlenmesinde "doğma" (G.V.K. md. 37, md. 52, md. 65), "tahsil edilen veya tahakkuk eden hasılat" (G.V.K. md. 39, md. 55), "ödeme" (G.V.K. md. 61), "nakden veya hesaben ödeme" (G.V.K. md. 96) gibi farklı kavramlar kullanılmaktadır (Öncel vd., 2012: 248-249). Bu kavramlar gelirin hukuki veya fiili tasarrufu ${ }^{10}$ anlamına gelmektedir (Erginay, 1995: 156). Dolayısıyla gelirin elde edilmesi, geliri meydana getiren kazanç ve iratların fiilen veya hukuken tasarruf edilebilir hale gelmesidir ${ }^{11}$ (Tosuner \& Arıkan, 2017: 22-23). Diğer bir deyişle elde etme, bir değerin kişinin mal varlığına katılmasıdır ve bu katılım tahsil veya tahakkuk esaslarına göre olmaktadır. Tahsil esası, gelirin nakit, ayın veya bir hak olarak kişinin mal varlığına dahil olması anlamına gelirken; tahakkuk esası, hukuken bir gelire alacaklı olmayı yani kişinin malvarlığına fiilen maddi bir değer girmemekle birlikte alacaklarında bir artış söz konusu olmasıdır (Şenyüz: 2007: 45-46). Türk vergi sisteminde ticari ve zirai kazançlarda tahakkuk esası kabul edilirken, diğer gelir unsurları için tahsil esası benimsenmiştir (Pehlivan, 2011: 146; Öncel vd., 2012: 252-253). Bu nedenle ücretlerde elde etmede tahsil esası geçerlidir. Yani ücretlerde elde etme, gelirin nakdi, ayni veya para ile temsil edilebilen bir menfaat şeklinde kişinin malvarlığına dahil olmasıdır.

\section{4. Ücret Gelirlerinin Vergilendirilme Esasları}

G.V.K.'ya göre ücret gelirleri "gerçek usul" ve "diğer ücretler" şeklinde iki usulde vergilendirilmektedir. Bunun yanında bazı mükellef grupları için geçici maddelerle özel vergilendirme usulleri belirlenmiştir.

\subsubsection{Gerçek Usul}

Ücret gelirlerinde matrahın tespiti ilke olarak gerçek usule göre yapılır (Öncel vd., 2012: 290). Gerçek usulde vergilendirme, işveren tarafından para ve ayınlarla

\footnotetext{
9 Vergi Usul Kanunu'nun 19. maddesine göre vergi alacağı, vergi kanunlarının vergiyi bağladıkları olayın vukuu veya hukuki durumun tekemmülü ile doğar.

10 Hukuki tasarruf; bir hizmetin yapılması ya da bir malın satılması karşılığında, bir kişinin alacak hakkının doğması anlamına gelirken; fiili tasarruf, gelirin para veya ayın olarak kişinin malvarlığına girmesi yani tahsilidir (Erginay, 1995: 156-157).

11 Gelirin elde edilmesine ilişkin farklı tanımlamalar ve ayrıntılı açıklamalar için bkz., Kaneti, 1986/1987: 269-270; Öncel vd., 2012: 248-253; Saban, 2006: 332-351.
} 
sağlanan menfaatler şeklinde yapılan ödemelerin gayrisafi toplamından, G.V.K.'nun 63. maddesinde sayılan indirimlerin yapılması suretiyle gerçekleştirilecektir. Mali gücü gayrisafi gelir değil, safi gelir temsil ettiğinden (Başaran Yavaşlar, 2012: 7) safi ücrete ulaşmak için bu indirimlerin yapılması gerekir (Tosuner \& Arıkan, 2017: 105). G.V.K.'nun 63. maddesinde sayılan bu indirimler; sosyal güvenlik kurumlarına yapılan ödemelerden, bazı kurum ve birliklere ödenen aidat ve primlerden, Türkiye'de kain sigorta ve emeklilik şirketlerine ödenen katkı payları ile sendikalara ödenen aidatlardan oluşur ve bu yönüyle son derece sınırlıdır (Biyan \& Yılmaz, 2012: 193).

Ücretin safi tutarının tespitinde G.V.K.'nun 63. maddesinde sayılan indirimler dışında başkaca indirimler de söz konusudur. G.V.K.'nun 31. maddesinde "engellilik indirimi" düzenlenmiştir. Buna göre çalışma gücünün belirli bir yüzdesini kaybetmiş olan hizmet erbaplarının ${ }^{12}$ ücretlerinden, engellilik derecelerine göre belirlenen aylık tutarlar $^{13}$ indirilecektir. Engellilik indiriminden engelli ücretliler, bakmakla yükümlü olduğu engelli kişi bulunan ücretliler, engelli serbest meslek erbapları, bakmakla yükümlü olduğu engelli kişi bulunan serbest meslek erbapları ve basit usulde vergilendirilen engelliler yararlanabilecektir (GiB, 2017b: 4). Dar mükellefiyete tabi olanlar ise engellilik indiriminden yararlanamaz (Tosuner \& Arıkan, 2017: 108).

Engellilik indirimi dışında diğer bir indirim de "asgari geçim indirimi"dir. Asgari geçim indirimi ücretin gerçek usulde vergilendirilmesinde uygulan bir indirimdir. Diğer ücretler kapsamında vergilendirilen hizmet erbapları asgari geçim indiriminden faydalanamaz. Asgari geçim indirimi tutarı, asgari ücretin yıllık brüt tutarına ${ }^{14}$ asgari geçim indirimi oranının ${ }^{15}$ uygulanması ile bulunan matraha, gelir vergisi tarifesinin birinci dilimine karşılık gelen oran (\% 15) ile çarpımı sonucu bulunur ve bulunan bu yıllık tutar 12'ye bölünerek asgari geçim indiriminin aylık tutarı belirlenir. Ücretlinin asgari geçim indiriminden faydalanabileceği azami tutar, ücreti üzerinden hesaplanan gelir vergisi ile sınırlıdır yani indirim tutarı hesaplanan gelir vergisini aşamayacaktır ${ }^{16}$ (Beyanname Düzenleme Kılavuzu, 2013: 129).

Ücretin safi tutarının tespitinde yapılacak diğer indirimler ise G.V.K.'nun 89. maddesinde sayılmıştır. Bu maddeye göre gelir vergisi beyannamesinde bildirilecek gelirlerden bir takım indirimler yapılabilecektir. Bu indirimler; belirli şartlar altında mükellefin şahsına, eşine ve küçük çocuklarına ait hayat sigortalarına ödenen primlerin $\% 50$ ' si ile ölüm, kaza, hastalık, sağlık, engellilik, analık, doğum ve tahsil gibi şahıs sigorta primlerini, yine belirli şartlar altında mükellefin kendisi, eşi ve küçük çocukları adına yapılan eğitim, sağlık harcamaları ile makbuz karşılığı yapılan bağış ve yardımları

12 Çalışma günün asgari \% 80'ini kaybeden hizmet erbabı 1. derece engelli, çalışma günün asgari \% $60^{\prime} ı$ ı kaybeden hizmet erbabı 2. derece engelli, çalışma günün asgari \% 40'ını kaybeden hizmet erbabı 3. derece engelli sayılır.

132017 yılı için 1. derece engelliler aylık 900 TL, 2. derece engelliler aylık 470 TL, 3. derece engelliler aylık 210 TL engellilik indiriminden faydalanırlar.

142017 yılı için aylık 1.777,50 TL, yıllık 21.330 TL'dir.

15 Asgari geçim indirimi oranı belirlenirken; mükellefin kendisi için \% 50, çalışmayan ve herhangi bir geliri olmayan eşi için \% 10, ilk iki çocuk için ayrı ayrı \% 7,5, üçüncü çocuk için \% 10 ve diğerleri için \% 5 dikkate alınır.

162017 yılı için yararlanılabilecek azami asgari geçim indirimi tutarı 226,63 TL'dir. 
kapsamaktadır. Burada dikkat edilmesi gereken husus, hizmet erbaplarının bu indirimlerden yararlanabilmeleri için vergilendirmenin yıllık beyanname usulüne göre yapılmasının gerekliliğidir.

Ücretin gerçek usulde vergilendirilmesi kaynakta kesinti (stopaj) ve yıllık beyanname usulü olmak üzere 2 şekilde yapılır.

\subsubsection{Kaynakta Kesinti (Stopaj) Usulü}

Gerçek usule tabi ücretler genel olarak stopaj usulüyle vergilendirilir ve bu vergilendirme ücretliler için nihai vergilendirme niteliği taşır (Öncel vd., 2012: 292). İşverenler hizmet erbabının ücretini öderken bu ücrete isabet eden vergiyi hesaplayıp, ilgili vergi dairesine vergi sorumlusu sıfatıyla yatırmak zorundadırlar (Armağan, 2006: 329).

G.V.K.'nun "Vergi Tevkifatı" başlıklı 94. maddesinde ; kamu idare ve müesseseleri, iktisadi kamu müesseseleri, sair kurumlar, ticaret şirketleri, iş ortaklıkları, dernekler, vakıflar, dernek ve vakıfların iktisadi işletmeleri, kooperatifler, yatırım fonu yönetenler, gerçek gelirlerini beyan etmeye mecbur olan ticaret ve serbest meslek erbabı, zirai kazançlarını bilanço veya zirai işletme hesabı esasına göre tespit eden çiftçilerin hizmet erbaplarına ödedikleri ücretler ile 61. maddesindeki ücret sayılan ödemelerden (istisnadan faydalananlar hariç) 103. ve 104. maddelere göre vergi kesintisi yapmak zorundadırlar. G.V.K.'nun 103. maddesinde gelir vergisi tarifesi yer alırken, 104. maddesinde, verginin vergiye tabi yıllık gelir toplamından 31. maddede yer alan indirimlerin düşülmek suretiyle 103. maddede yer alan tarifenin uygulanmak suretiyle hesaplanacağı belirtilmiştir. Bunun yanında G.V.K.'nun 86. maddesine göre tek işverenden alınan ve tevkif suretiyle vergilendirilen ücretler için yıllık beyanname verilmeyecektir, yani yapılan tevkifat nihai vergilendirme olacaktır. Birden fazla işverenden alınmakla birlikte birden sonraki işverenden alınan ücretler toplamı G.V.K.'nun 103. maddesinde yer alan tarifenin ikinci diliminde yer alan tutarı (2017 yılı için $30.000 \mathrm{TL}$ ) aşmaması halinde yine yapılan tevkifat nihai vergilendirme niteliğinde olacaktır.

\subsubsection{Yıllık Beyanname Usulü}

Ücret gelirlerinin vergilendirilmesinde esas tevkifat usulü olmasına rağmen, bazı hallerde ücretler yıllık beyanname verilmek suretiyle vergilendirilecektir. G.V.K.'nun 95. maddesine göre; ücretlerini yabancı bir ülkedeki işverenden doğrudan doğruya alan hizmet erbapları, G.V.K.'nun 16. maddesinde yazılı istisnadan faydalanmayan yabancı elçilik ve konsolosluk memur ve hizmetlileri, Maliye Bakanlığı'nca yıllık beyanname ile bildirilmesi gereken ücretler yıllık beyanname verilmek suretiyle vergilendirilir. Bunun yanında G.V.K.'nun 86/1-b maddesi uyarınca birden fazla işverenden ücret alan hizmet erbaplarının birinci işverenden sonraki işverenlerden aldıkları ücretler toplamı, gelir vergisi tarifesinin ikinci diliminde yer alan tutarı (2017 yılı için 30.000 TL) aşması halinde, birinci işveren dahil tüm işverenlerden alınan ücretler için yıllık beyanname verilecektir. 


\subsubsection{Diğer Ücretler}

Ücretlilerin tamamının gerçek usulde vergilendirilmesi safi ücretin tespitinde meydana gelen zorluklar nedeniyle her zaman mümkün değildir. Özellikle hesap tutamayan ya da tutmak zorunda olmayan kişilerce verilen ücretlerde ücretin gerçek tutarını belirlemek oldukça zordur. Bu nedenle hem vergi daireleri hem de işverenler için gereksiz zorluklara sebebiyet verilmemesi amacıyla (Tosuner \& Arıkan, 2017: 119), gelirin elde edilmiş ve safi tutar üzerinde vergilendirilmesi ilkelerinde saparak (Öncel vd., 2012: 291) bazı ücretliler için farklı bir vergilendirme usulü belirlenmiştir. G.V.K.'nun 64. maddesine göre; kazançları basit usulde tespit edilen ticaret erbabının yanında çalışanlar, özel hizmetlerde çalışan şoförler, özel inşaat sahiplerince ücretle çalıştırılan inşaat iş̧̧ileri, gayrimenkul sermaye iradı sağlayanların yanında çalışanlar ve gerçek ücretlerinin tespitine imkan olmaması nedeniyle, Danıştay'ın olumlu görüşüyle Maliye Bakanlığı'nca bu kapsama alınanların safi ücretleri, takvim yılı başında geçerli olan ve sanayi kesiminde çalışan 16 yaşından büyük iş̧̧iler için uygulanan asgari ücretin yıllık brüt tutarının \% $25^{\prime}$ idir $^{17}$. Hesaplanan vergi hizmet erbabı tarafından vergi dairesine ödenir ve bu işlemler hizmet erbabınca vergi dairesinden alınacak vergi karnesi aracılı̆̆ıla yerine getirilir (Şenyüz vd., 2011: 68).

Diğer ücretliler için yıllık beyanname verilmemektedir, diğer gelirler nedeniyle beyanname verilse dahi bunlar beyannameye dahil edilmeyecektir.

\subsection{3. Özel Vergilendirme Rejimine Tabi Ücretler}

G.V.K.'na göre tevkifat suretiyle vergilendirilen ücretler bakımından özel hükümlere tabi iki farklı grup karşımıza çıkmaktadır. Bunlardan ilki Türkiye Jokey Kulübünce organize edilen yarışmalara katılan atların jokeyleri, jokey yamakları ve antrenörleri diğeri de sporculardır. Söz konusu kişilerin elde ettikleri ücretler Kanunun genel hükümleri yerine özel esaslara göre yapılır.

\subsubsection{Jokey, Jokey Yamakları ve Antrenörlere Yapılan Ücret Ödemelerinin Vergilendirilmesi}

Ülkemizde Türkiye Jokey Kulübü (TJK)'nce organize edilen yarışmalara katılan atların jokeyleri, jokey yamakları ve antrenörlerinin elde ettikleri ücretler uzun yıllar G.V.K.'nun 23/2 maddesi kapsamında değerlendirilerek vergi dışı bırakılmıştır. Anılan madde hükmüne göre gerçek usulde vergilendirilmeyen çiftçilerin yanında çalışan işçilerin ücretleri vergiden müstesnadır. 4761 sayılı Kanunla G.V.K.'nun 94. maddesine eklenen "Maliye Bakanlığı, vergiye tabi işlemlere taraf veya aracı olanları verginin ödenmesinden sorumlu tutabilir" hükmü çerçevesinde yayımlanan 247 seri no'lu Gelir Vergisi Genel Tebliği ile bu kişilere, at sahipleri adına Türkiye Jokey Kulübü'nce yapılacak ücret ve ikramiye ödemelerinden gelir vergisi tevkifatı yapılması uygun bulunmuştur. 5281 sayılı Kanunun 30. maddesiyle Kanuna eklenen geçici 68. maddeye göre 31.12.2020 tarihine kadar TJK tarafından organize edilen yarışmalara katılan atların jokeyleri, jokey yamakları ve antrenörlerine ücret olarak yapılan ödemeler

\footnotetext{
${ }^{17} 2017$ yılı için asgari ücretin brüt tutarı 1.777,50 TL, yıllık tutarı 21.330,00 TL (1.777,50 x 12), diğer ücret matrahı 21.330,00 x \% 25=5.332,50 TL, ödenecek vergi 5.332,50 x \% 15= 799, 88 TL'dir.
} 
üzerinden \% 20 gelir vergisi tevkifatı yapılır. Ödemeyi yapanın 94. madde kapsamında tevkifat yapma zorunluluğu bulunup bulunmamasının ödenecek gelir vergisine etkisi yoktur. Türkiye Jokey Kulübü aracılığıyla yapılan ücret ödemelerinde Gelir Vergisi tevkifatı bu kulüp tarafından yerine getirilir. Yapılan gelir vergisi tevkifatı sözü edilen ücretliler için nihai vergi olur ve bu gelirler için yıllık beyanname verilmez, diğer gelirler için beyanname verilmesi halinde bu gelirler beyannameye dahil edilmez.

At Yarışları Yönetmeliği'nin ${ }^{18}$ 58. maddesi gereğince yapılan yarışlarda ilk dört dereceye giren atlar için ikramiye verilir. At sahipleri kazandıkları ikramiyeler üzerinden atlarını idman ettiren antrenörlerine, jokey (koşuya katılmışsa apranti) ve seyise prim verirler. Bu primler Yönetmeliğin 90 ve 105. maddelerine göre Yarışma Müessesesince $^{19}$ at sahibine ikramiye ödemesi yapılırken kaynakta kesilir. TJK tarafından at sahibinin talimatlarına göre -ilgililer ile arasında özel bir anlaşma olmaması halinde- antrenör için \% 10, jokey için \% 10 ve apranti için \% 5 oranında kesinti yapılmaktadır. TJK tarafından kesilen bu tutarlar at sahibi adına antrenör, jokey ve aprantilere ödenmektedir. At Yarışları Yönetmeliği'nin 105. maddesine göre jokeyler ve aprantiler ile antrenör ve seyislerin primleri hesaplanırken, yalnızca ikramiye dikkate alınır. Yetiştiricilik primi, kaydiye ve taksit paraları ile varsa ayni ve nakdi ödüllerin değeri hesaba katılmaz. Kesintiler ve dağıtıma ilişkin bilgiler Tablo 1'de yer almaktadır.

Tablo 1: 100 TL Yarış İkramiyesinin TJK Tarafından ilgililere Dağıtılması

\begin{tabular}{|c|c|c|c|c|c|}
\hline $\begin{array}{c}\text { Yarış } \\
\text { Atının }\end{array}$ & $\begin{array}{l}\text { Gelirin } \\
\text { Unsuru }\end{array}$ & Prim Oranı & $\begin{array}{c}\text { Ödemeyi } \\
\text { Yapan }\end{array}$ & $\begin{array}{c}\text { Tevkifat } \\
\text { Oranı }\end{array}$ & Yıllık Beyanname \\
\hline Sahibi & Zirai Kazanç & $\% 75-80$ & TJK & $\% 2$ & Vermez \\
\hline Antrenörü & Ücret & $\% 2,5-10$ & TJK & $\% 20$ & Vermez \\
\hline Jokeyi & Ücret & $\% 7-10$ & TJK & $\% 20$ & Vermez \\
\hline Aprantisi & Ücret & $\% 2,5-5$ & TJK & $\% 20$ & Vermez \\
\hline & Ücret & $\% 2,5-5$ & & & Vermez \\
\hline Seyisi & Ücret & Maaş & At sahibi & Tevkifat yok & $\begin{array}{llr}\text { Tek ata bakarsa maaşı } \\
1.520 \text { TL; } & \text { iki ata } & \text { bakarsa } \\
\text { maaşı } 1.750 \quad \text { TL'dir } \\
\text { Vergiden istisnadır. }\end{array}$ \\
\hline İkramiye Tutarı & Sahibi & Jokey & Antrenör & Apranti & Seyis \\
\hline \multirow{2}{*}{$100 \mathrm{TL}$} & $75 \mathrm{TL}$ & $10 \mathrm{TL}$ & $10 \mathrm{TL}$ & - & $5 \mathrm{TL}$ \\
\hline & $80 \mathrm{TL}$ & - & $10 \mathrm{TL}$ & $5 \mathrm{TL}$ & $5 \mathrm{TL}$ \\
\hline \multirow{2}{*}{ Kesilecek vergi } & 1,47 TL & \multirow{2}{*}{ 1,67 TL } & \multirow{2}{*}{ 1,67 TL } & \multirow{2}{*}{ 0,83 TL } & \multirow{2}{*}{ Tevkifat yok } \\
\hline & 1,56 TL & & & & \\
\hline
\end{tabular}

Kaynak: http://medya.tjk.org/medyaftp/pdf/At_Yarislari_Yonetmeligi.pdf yararlanılarak tarafımızdan hazırlanmıştır.

18 RG: 27910 - 19.04.2011

19 “...Türkiye Jokey Kulübü, 3 Ekim 1953 tarihinden beri 6132 sayılı Kanunun 5. maddesine uygun olarak ve Tarım ve Köyişleri Bakanlığı'ndan aldığı yetkiyle at yarışlarını düzenlemektedir. Bu sözleşmelerin sonuncusu 31 Aralık 2017 tarihine kadar yenilenmiştir...", http://www.tjk.org/TR/Kurumsal/ Static/Page/Tarihce, (01.03.2017). 
Yarışmalarda kazanılan ikramiyenin at sahibi ile atı yarışa hazırlayan diğer kişiler arasında pay edildiğinde en büyük payı \% 75 ile at sahipleri almaktadır. Atları yetiştirip yarışlara katılan at sahiplerinin bu faaliyetleri zirai faaliyet sayılmakta (Tosuner \& Arıkan, 2017: 83) dolayısıyla da yarışlar nedeniyle at sahiplerine ödenecek ikramiyeler, zirai kazanç olarak gelir vergisinin konusuna girmektedir (28 Seri No'lu Veraset ve Intikal Vergisi Kanunu Genel Tebliği). Yine yarış atı yetiştirici ve sahiplerine yapılan ödemelerden (teşvik primi ve ikramiye gibi ödemeler dahil) G.V.K.'nun 94. maddesi uyarınca \% 2 oranında gelir vergisi tevkifatı yapılır ve işletme büyüklüğü ölçüsünü aşmayan çiftçiler için kesilen bu vergi nihai vergi olur (219 Seri No'lu Gelir Vergisi Genel Tebliği). G.V.K.'nun 54. maddesine göre iki yaşından küçükler hariç olmak üzere 150 adetten daha az büyükbaş hayvanı olan çiftçiler bir biçerdövere veya bu mahiyetteki bir motorlu araca veya on yaşına kadar ikiden fazla traktöre sahip olmamaları durumunda gerçek usulde vergilendirilmezler. Başka bir ifadeyle diğer şartları haiz olmak kaydıyla 150 adetten daha fazla bir sayıda yarış atına sahip olmayan kişiler için ikramiye ödenmesi sırasında yapılan vergi kesintisi nihai vergi olur ve bu kişilerin gelir vergisi beyannamesi vermelerine gerek yoktur. Bazen işadamlarını bile yaşadıkları ekonomik krizden kurtarmaya yetecek kadar büyük tutarlarda ikramiye kazandıran ve yapılan yatırımın 6 misli olarak geri döndüğü (Cingi, 2010) sektörde kazanılan bu ikramiyelerin cüzi derecede vergilendirilmesi mali güce göre vergilendirme ilkesi ile bağdaşmadığı gibi adil de sayılmaz. Değeri çoğu zaman milyon dolarlar ile ifade edilen yarış atlarından iyi cins elde etmek için aygır sahibine ödenen meblağlar (Munyar, 2011) da göz önünde bulundurulduğunda olayın vahameti daha da artmaktadır. Atın yaşam süresi boyunca sadece belli yaş aralığında katılabildiği riski bu kadar yüksek bir işe pek çok kişi tarafından çok ciddi tutarda sermaye bağlanmaktadır. Nihayetinde hiç kimse iyi para kazanmadığı ya da kazanma ihtimalinin düşük olduğu bir işe -hele hele güdüleriyle hareket edebilen bir canlıya- yatırım yapmaz. Aynı zamanda bu çıkarını her daim en üst düzeyde tutmaya çalışan insanın yaradılışına da aykırıdır. Gelir ve kurumlar vergisi mükellefleri analiz edilse acaba kaç tanesinin sermayesi milyon dolarla ifade edilir. Dolayısıyla kazanılan ikramiyeden en büyük payı almasına rağmen yanında çalıştırdığı kişilerin tamamından daha düşük oran ve tutarda vergi ödeyen at sahibinin durumu aynı zamanda vergilemenin ruhuna da aykırıdır.

\subsubsection{Sporculara Yapılan Ücret Ödemelerinin Vergilendirilmesi}

G.V.K.'nun geçici 72. maddesine göre 31.12.2017 tarihine kadar sporculara yapılan ücret ve ücret sayılan ödemeler tevkif suretiyle vergilendirilmekte ve bu vergileme nihai vergi olmaktadır. Söz konusu madde gereğince yapılan ödemelerden lig usulüne tabi olan spor dallarında; en üst ligdekiler için \% 15, bir alt ligdekiler için \% 10 ve diğer liglerdekiler için \% 5 , lig usulüne tabi olmayan spor dallarında (milli sporculara uluslararası müsabakalara katılmaları karşılığında yapılan ödemeler dahil) ise \% 5 oranında gelir vergisi tevkifatı yapılmaktadır. Bu ödemeler G.V.K.'nun 94. maddesine göre ayrıca tevkifata tabi tutulmadığı gibi yıllık beyanname ile de beyan edilmez. Diğer gelirler için beyanname verilmesi durumunda da bu gelirler beyannameye dahil edilip 
toplanmaz. Tablo 2'de 1999 yılından itibaren sporcuların vergilendirilme usullerine ilişkin bilgiler yer almaktadır. Tablodan da anlaşılacağı üzere sporcularının vergilendirilme usulü bir takım değişikliklerle birlikte bugünkü halini almıştır.

Tablo 2: 1999 Yılından İtibaren Sporcuların Vergilendirilmesi

\begin{tabular}{|l|l|}
\hline 01.01.1999 - 24.04.2003 Dönemi & Genel hükümlere göre vergilendirilmişlerdir. \\
\hline 24.03.2003 - 30.06.2008 Dönemi & $\begin{array}{l}\text { 31.12.2007 tarihine kadar \%15 oranında gelir vergisi stopajına tabi } \\
\text { tutulmuştur. }\end{array}$ \\
\hline 01.07.2008 ve sonrası & $\begin{array}{l}\text { Geçici 72. maddeye göre ligler itibariyle farklı oranlarda gelir vergisi } \\
\text { stopajına tabi tutulmuştur. }\end{array}$ \\
\hline
\end{tabular}

Amatör sporculara ödenen ikramiyeler ile verilen ödüller G.V.K.'nun 29. maddesine göre istisna hükümlerinden faydalanırken profesyonel sporcular için kulüplerince verilecek ödül ve ikramiyeler genel hükümlere göre ücret olarak vergiye tabi tutulacaktır ${ }^{20}$.

\subsubsection{Muafiyet ve İstisnalar ${ }^{21}$}

G.V.K.'nda ekonomik, sosyal ve teşvik etmek amaçlarına yönelik olarak bir takım vergi konularının vergiden istisna edildiği, bir takım mükellef gruplarının ise vergisinden muaf tutulduğu görülmektedir. Ücretliler açısından muafiyet ve istisna hükümleri G.V.K.'nun 15., 16., 23., 24., 25., 26., 27., 28., 29. maddelerinde düzenlenmektedir.

\section{Vergilendirmede Adalet ilkesi}

Vergilendirmede adalet ilkesi klasik maliyenin, modern maliyenin ve az gelişmiş ekonomilerin uyguladıkları vergi politikasının temel prensiplerinden biri olmuştur (Türk, 1992: 159). Adalet, bir olması gerekendir, ama olması gerekenin ne olduğu belirsizdir ve yanıtı her zaman bir değer yargısını içerir (Yaltı Soydan, 1998: 98). Bu nedenle kavrama çeşitli açılardan anlam yüklemek mümkündür. Normatif (Sheffrin, 1993: 301) bir kavram olan adalet; zamana, mekana, değer yargılarına, toplumlara ve hatta toplumu oluşturan kişi ve gruplara göre değişmekte psikolojik ve izafi bir algı (Topuzkanamış, 2013: 111) olarak karşımıza çıkmaktadır. Adalet kavramının literatürde hukuk kavramı ile somutlaştığı, her hukuk düzeninin kendine özgü adalet anlayışının olduğu ve hukuk kurallarının uygulanması sonucunda adaletin ortaya çıkacağı ifade edilir (Deyneli, 2010: 6-8). Burada asıl problem adalet kavramının çok değişik şekillerde yorumlanmasından kaynaklanmaktadır. Kavramın tanımlanmasında karşılaşılan bu belirsizlik, vergileme açısından izahına da sirayet etmiştir. Nitekim bir yandan verginin tarafsızlığı için kullanılırken diğer yandan kişinin sahip olduğu vergi ödeme gücüne göre

${ }^{20}$ Gelir İdaresi Başkanlığı Kocaeli Vergi Dairesi Başkanlığı Mükellef Hizmetleri Grup Müdürlüğü’nün 28.02.2012 tarih ve B.07.1.GiB.4.41.15.01-G.V.K.-2011/11-53 sayılı Özelgesi.

${ }^{21}$ Konunun ana temasından uzaklaşmamak adına ayrıntıya yer verilmemiştir. İleriki bölümlerde vergi adaleti açısından konu incelenecektir. 
vergilendirilmesini ifade eder. Dolayısıyla tarihsel süreçte değişik şekillerde yorumlanmasına rağmen kavramın herkes tarafından kabul edilebilir bir şekilde sınırları hala çizilememiştir. Vergi adaletini, kelime olarak söylemek kolaydır. Fakat tamamıyla etnik olan bu kavramı maddi şekilde ve fiili sahada tahakkuk ettirmek zordur (Hanyal, 1964: 66). Bütün bunlara rağmen maliyeciler yıllardır bu ilkeyi şiddetle savunmaya devam ederek kişiler arasındaki vergi dağıtımının ahlaken tatmin edici bir şekilde düzenlenmesini hedeflemişlerdir. Gelinen nokta itibariyle bir toplum içinde yer alan kişilerin vergi ödeme güçleri ölçüsünde vergi yüküne katılmaları vergilemede adalet ilkesi olarak ifade edilebilir (Akdoğan vd., 1986: 193).

Adalet kavramının dağıtıcı ve denkleştirici olmak üzere iki yönde incelenmesi mümkündür. Dağıtıcı adalet, ayırıcı özelliklerine göre kişilerin farklı işlemlere tabi tutulması anlamına gelir. Kişilerin eşit işleme tabi tutulması ise denkleştirici adaleti ifade eder. Vergi adaleti bakımından konu irdelendiğinde yazarların konuya mali güç yaklaşımı ve fayda yaklaşımı olmak üzere iki farklı açıdan yaklaştığı görülür (Karakoç, 2013: 1285). Herkesin ayrıma tabi olmaksızın mali gücüne göre vergi ödemesi mali güç yaklaşımının bir sonucudur. Mali gücün ne olduğu Anayasa'da tanımlanmamış ${ }^{22}$ olmakla birlikte kamu maliyesi yönünden bilimsel göstergeleri gelir, servet ve harcama olarak kabul edilir (Kızılot vd., 2007: 31) ve genellikle ödeme gücü anlamında kullanılır (Arıkan, 2005: 153). Fayda yaklaşımına göre ise kişilerin kamu hizmetlerinden yararlandıkları nispette kamu giderlerine katılmaları beklenir. Bu durumda vergi, kişinin devletin sunmuş olduğu koruma ve benzeri hizmetler karşılığında vatandaşlık ödevi olarak ödediği fiyat ya da pay haline gelir (Yereli \& Ata, 2011: 25). Adam Smith bu yaklaşımı vergide adaletin temeli olarak görmüş ve kişilerin ödeme güçlerine göre vergilendirilmeleri halinde bunun o kişilerin devletten sağladıkları hizmetlerin ölçüsünü teşkil edeceğini ileri sürmüştür (Uluatam, 1991: 225). Anayasa'nın 73. maddesinde; vergileme, "mali gücüne göre" ifadesiyle faydalanma yaklaşımına değil mali güç yaklaşımına dayandırımış ve hüküm altına alınmıştır (Mutlu, 2009: 107). Maddede herkesin mali gücüne göre vergi ödemekle yükümlü olduğu, vergi yükünün adaletli ve dengeli dağıtılması gerektiği açıkça belirtilmiştir. Görüldüğü üzere soyut olarak Anayasada sınırları ifade edilen adalet kavramının meşruluğu vergi yükünün dengeli ve adaletli dağılımına bağlanmıştır. Nitekim verginin mali güce göre alınması, aynı zamanda eşitlik ilkesinin vergilendirmede uygulama aracıdı ${ }^{23}$. Zaten adil ve dengeli bir vergi politikası, sosyal devlet anlayışının da vazgeçemeyeceği ilkelerden birisi ${ }^{24}$ olmalıdır. Hüküm dikkate alındığında, dar anlamda vergi açısından mali güç ön planda tutulurken, bunun dışında kalan geniş anlamdaki vergi unsurları bakımından ise fayda esasının uygulanmasına imkan tanınmıştır (Erdem, 2013: 52).

\footnotetext{
22 “...bir vergi için modern vergi prensiplerinin ve mali gücü belirtecek ölçülerin ayrıca kanunda gösterilmemiş olmasının uygulama bakımından bir eşitsizlik doğurmayacağı ve esasen ne insan haklarına, ne sosyal adalete, ne de hukuk devleti ve kanun önünde eşitlik ilkelerine bir aykırılık sayılamayacağı açıktır...", Anayasa Mahkemesi'nin 05.01.1965 tarih ve E. 1963/198, K. 1965/1 Sayılı Kararı

23 Anayasa Mahkemesi'nin 13.07.1995 tarih ve E. 1994/85, K. 1995/32 Sayılı Kararı

24 Anayasa Mahkemesi'nin 24.06.1993 tarih ve E. 1992/29, K. 1993/23 Sayılı Kararı
} 
Vergide adalet; ilgili kanuni düzenlemeler yapılırken kanun koyucunun adalet düşüncelerine ve temel vergi ilkelerine göre şekillenmektedir. Durum böyle olmakla birlikte, gerçekleşmesi öngörülen adaletin uygulama bakımından da sağlanması gerekir. Dolayısıyla adil olarak hazırlanmış vergi kanunlarının yine adalete ters düşmeyecek şekilde etkin bir biçimde uygulanması gerekir (Akdoğan, 2011: 205). Vergilendirmede adaletin sağlanması bakımından dikkat edilmesi gereken bir diğer husus da ülkede yaşayan herkesin devletin üstlendiği giderlere katılması gerekliliğidir. Çünkü Devlet, topladığı gelirler ile topluma yönelik faydalar sağlar. Toplumda yerli ve yabancılar olabildiği gibi dili, dini, ırkı, cinsiyeti veya siyasi düşüncesi farklı insanlar da olabilir. Vergileme tarihi boyunca ülkemizde ve Dünyada aksine uygulamaların varlığı bilinmesine rağmen günümüzde Anayasa'mızın 10. maddesinde de açıkça hüküm altına alındığı gibi herkes sayılan bu farklılıklar nedeniyle ayırım gözetmeksizin kanun önünde eşittir. Hiçbir kişiye, aileye, zümreye veya sınıfa imtiyaz tanınamayacağı gibi istisnai durumlar hariç özel düzenleme de yapılamaz. Bu nedenle ülkemizde yaşayan ve ödeme gücüne sahip herkes hiçbir ayrım gözetmeksizin vergi vermek durumundadır. Yine 73. maddede geçen "Herkes, kamu giderlerini karşılamak üzere, mali gücüne göre, vergi ödemekle yükümlüdür" hükmü de bu ifadeyi destekler mahiyettedir. Literatürde bu durum vergilemede genellik ilkesi olarak adlandırılır ve hemen hemen tüm ülkeler yaptıkları vergisel düzenlemelerde vergilendirmede adaleti sağlamak adına -iktisadi, politik ve sosyal zorunluluklardan kaynaklanan nedenler dışında- aksine hareket etmezler. Bu durum aynı zamanda vergilemenin amaçlarına da uygunluk göstermektedir. Çağdaş maliyeciler arasında tamamıyla olmasa da adil bir vergilemenin özellikle de kişiler arasında adil vergi dağıtımının ancak genellik, eşitlik ve nisbilik ilkelerinin yerine getirildiği zaman söz konusu olabileceği yönünde görüş birliği vardır (Neumark, 1975: 75).

\section{4. Ücret Gelirlerinin Vergilendirilmesinin Vergi Adaleti Açısından Değerlendirilmesi}

\section{1. Özel Vergilendirme Rejimine Tabi Ücretlerin Değerlendirilmesi}

\subsubsection{Jokey, Jokey Yamakları ve Antrenörlerinin Ücretleri}

2016 yılında TJK'nün organize ettiği yarışlarda 367 jokey tarafından kazanılan toplam ikramiye tutarı 338.821.211 TL'dir. Dağıtılan ikramiye tutarı -73 jokey/apranti hiç gelir elde etmemesine rağmen- kişi başı ortalama 923.218 TL' dir. En fazla dereceye giren jokeyin ikramiyelerden kazandığı toplam tutar ise 23.695.269 TL' dir. Jokeyin yarışlardan kazandığı bu tutar istisnai bir örnek olmakla birlikte çok ciddi bir tutardır. Bu kadar başarılı bir jokeyin -\% 10'dan daha düşük bir oranda prim elde etmeyeceği varsayımı altında- kaynakta \% 20 oranında vergilendirilmesi ve bu geliri için yıllık gelir vergisi beyannamesi vermemesi aynı gelir düzeyine sahip ve beyanname veren ücretliler bakımından mali güce vergilendirme ilkesine aykırıdır. Keza kaynakta tevkif suretiyle vergilendirildiği için gelir vergisi beyannamesi vermeyen tek işverenden ücret geliri elde eden ücretliler açısından dahi durum incelendiğinde adil bir vergilendirmenin olmadığı açıktır. Çünkü anılan ücretler üzerinden yapılacak tevkifat 
G.V.K.'nun 103. maddesinde yer alan ve \% 15' den başlayıp \% 35' e kadar kademeli olarak artan vergi tarifesine göre yapılmaktadır. Diğer şartlar ihmal edildiğinde (23.695.269 X \% 10=) 2.369.526 TL prim elde eden ve kaynakta \% 20 oranında yapılan kesintiden (473.905 TL) başka vergisel sorumluluğu olmayan bu jokey 2016 yılı vergi tarifesine göre vergilendirilmiş olsaydı 817.804 TL vergi ödemesi gerekecekti. Az sayıda yarış kazanarak çok cüzi tutarlarda ikramiye elde jokey ile örnekte olduğu gibi oldukça yüksek tutarlarda gelir elde eden jokeyin aynı oranda kesinti yapılmak suretiyle vergilendirilmesi kişilerin vergi ödeme güçlerini dikkate almadığından haksızlıklara neden olmaktadır.

\subsubsection{Sporcuların Ücretleri}

Anayasamızın 59. maddesine göre devlet, sporun kitlelere yayılmasını teşvik eder ve başarılı sporcuları korur. Bu nedenle sporculara yönelik koruma ve teşvik hükümlerinin vergi kanunlarında yer alması kadar doğal bir durum yoktur. Ancak mevcut hükümler incelendiğinde uygulanan yöntem itibariyle ödeme gücü ilkesini hatta eşitlik ve adalet ilkelerini de zedeleyen bu durum literatürde bazı yazarlarca (Öz \& Akçay, 2013: 35-54) diğer ülkelere göre -özellikle futbolcular için- Türkiye'nin vergi cenneti olduğu şeklinde yorumlanmaktadır. Sahip oldukları malvarlıkları ve lüks içerisinde sürdükleri yaşam her gün medya kuruluşları vasıtasıyla topluma sunulurken ödedikleri vergi tutarı itibariyle oldukça gerilerde kalan sporcuların bu durumu aynı zamanda devlete olan güveni de sarsmaktadır. Nihayetinde vergiye gönüllü uyumu da etkileyebilecek istisnai bu düzenlemelerin daha da sınırlı tutulması gerekmektedir. Nitekim çok kazanıp az vergi ödeyen bu kimseler sürekli göz önünde bulunduklarından, asgari ücreti bile vergilendirmeyi hedefleyen idareyi güç durumda bırakmakta ve toplumun vicdanını yaralamaktadır.

Tablo 3'de görüldüğü üzere ülkemizde spor faaliyetlerinde oldukça yüksek tutarlarda ücret geliri elde eden sporcular da bulunmaktadır. Tespit edilebilen tutarlar itibariyle ödenmesi gereken gelir vergisi çok daha yüksek tutarda olmasına rağmen verginin kaynakta kesilmesi ve bu kesintinin nihai vergi olması nedeniyle vergi gelirleri bakımından erozyona neden olmaktadır. Başka bir ifadeyle artan oranlı gelir vergisi tarifesine göre hesaplanacak gelir vergisinden, kaynakta tevkif edilip tarh ve tahakkuk ettirilen gelir vergisinin düşülmesi sonucu bulunan tutar vergi harcamasıdır. Örneğin 1. Ligde oynayan ve $1.500 .000 €$ (kur 3,90 TL olarak dikkate alındığında 5.850.000 TL) ücret geliri elde eden bir futbolcuya ödeme yapılırken kaynakta \% 10 oranında $(5.850 .000 \times \% 10=585.000 \mathrm{TL})$ yapılacak vergi kesintisi nihai vergi olmaktadır. Futbolcunun bu geliri nedeniyle gelir vergisi beyannamesi vermesi durumunda tahakkuk ettirilecek gelir vergisi tutarı ise -2017 yılı vergi tarifesine göre- 2.035.950 TL olacaktır. Buna göre aradaki fark (2.035.950-585.000=) 1.450.950 TL vergi erozyonuna neden olmaktadır. Durum Maliye Bakanlığı tarafından da aynı şekilde kabul görmektedir (Vergi Harcamaları Raporu, 2016: 94). 
Tablo 3: En Çok İzlenen İki Spor Dalına İlişkin Sporcuların Aldığı Ücretler (2016/2017)

\begin{tabular}{|c|c|c|c|c|c|}
\hline \multirow{2}{*}{ Spor Dalı } & \multirow{2}{*}{\multicolumn{2}{|c|}{ Yer Aldığı Lig }} & \multicolumn{2}{|c|}{ Oyuncu sayısı } & \multirow{2}{*}{$\begin{array}{l}\text { (En Pahalı Oyuncu) } \\
\text { Son Transfer Ücreti }\end{array}$} \\
\hline & & & Yabancı & Yerli & \\
\hline \multirow{7}{*}{ Futbol } & \multicolumn{2}{|c|}{ Süper Lig } & 248 & 231 & $14.000 .000 €$ \\
\hline & \multicolumn{2}{|l|}{ 1. Lig } & 109 & 364 & $1.500 .000 €$ \\
\hline & \multirow{2}{*}{ 2. Lig } & Kırmızı Grup & 14 & 470 & $300.000 €$ \\
\hline & & Beyaz Grup & 11 & 508 & $500.000 €$ \\
\hline & \multirow{3}{*}{ 3. Lig } & 1. Grup & 7 & 518 & $300.000 €$ \\
\hline & & 2. Grup & 7 & 510 & $350.000 €$ \\
\hline & & 3. Grup & 3 & 489 & $300.000 €$ \\
\hline \multirow{3}{*}{ Basketbol } & \multicolumn{2}{|c|}{ Süperlig } & 128 & 130 & $2.500 .000 €^{25}$ \\
\hline & \multicolumn{2}{|l|}{ 1. Lig } & 46 & 182 & Maaş almaktadırlar \\
\hline & \multicolumn{2}{|l|}{ 2. Lig } & - & 236 & Maaş almaktadırlar \\
\hline
\end{tabular}

Kaynak: http://www.transfermarkt.com.tr/, http://basketbol.tblstat.net/players.asp?s=1617, adresinden yararlanılarak tarafımızdan hazırlanmıştır.

Sporcuların tevkif suretiyle vergilendirilmesi vergi sistemi bakımından ciddi bir tehdit unsurudur. Zira kendi içinde bile bir takım adaletsizlikleri barındırmaktadır. Çünkü bazı hallerde bir alt ligde olmasına rağmen meşhur kişiliği veya kulübün maddi imkanlarının yeterli olması nedeniyle üst ligdeki sporculardan daha yüksek tutarlarda gelir elde eden sporcular daha az vergi ödeyebilmektedir. Örneğin süper ligde toplam güncel değeri itibariyle en düşük tutara sahip bir futbol kulübünde ${ }^{26} 50.000 €-150.000$ $€$ arasında gelir elde eden futbolcu kendisinden çok daha fazla gelir elde eden bir alt ligdeki/liglerdeki ${ }^{27}$ sporculara nazaran daha yüksek oranda vergi ödemek durumunda kalmaktadır. Sporcuyu koruma gayesiyle liglere göre kademeli olarak azalan tevkifat uygulaması bu yönüyle çok kazananın daha az vergi ödemesi sonucunu ortaya çıkarmaktadır. Bu yönüyle bırakınız sporcuyu korumayı bilakis adaletsizliğin başlıca kötü örneği olmaktadır. Emekleriyle ancak kendi geçimini sağlamaya yetecek miktarda gelir sağlayan asgari ücretliyi, vergiden kaçınamayanları ve vergi kaçırmayanları incitmektedir. Durumun sporcuların çok kısa süre iyi gelir elde etmelerinden ${ }^{28}$ ve bu gelirin hayat boyu devam etmeyeceğinden hareketle makyajlanması kabul edilebilir bir izah olmamakla birlikte gerçekçi de değildir. Günümüz itibariyle futbol süper liginde mücadele eden en geç oyuncunun 16, en yaşlı oyuncunun da 38 yaşında

25 http://www.milliyet.com.tr/avrupa-da-en-cok-kazanan---2127798-skorerhaber/, (07.03.2017).

${ }^{26}$ (Adanaspor), http://www.transfermarkt.com.tr/super-lig/marktwerteverein/wettbewerb/TR1, (07.03.2017).

27 Bir alt lig olan 1. Ligde oynayan ve $1.500 .000 €$ gelir eden bir futbolcudan kaynakta \% 10 oranında vergi kesintisi yapılmaktadır.

282015 - 2016 Yılında süper ligde oynayan X Erkek Basketbol Takımında görev alan oniki oyuncunun aldıkları toplam maaş tutarı 12.055.000 € olup oyuncu başına ortalama gelir düzeyi 1.005.000 € civarındadır, http://orhanpehlivan.blogspot.com.tr/2015/09/fenerbahce-erkek-basketboltakimi.html, (07.03.2017). 
(www.transfermarkt.com.tr) olduğu dikkate alındığında ortalama 20 yıllık bir oynama süresi kısa sayılamayacak kadar uzun bir süre olmaktadır. Nitekim pek çok sporcu, sporu bıraktıktan sonra bile yorumcu, antrenör, yönetici veya menajer olarak çalışmaya dolayısıyla da yüksek gelir elde etmeye devam etmektedir. Başka bir ifadeyle doktorun, işçinin, memurun hatta öğretim üyesinin bile emeklisinin olduğu ülkemizde sporcunun özellikle de en üst ligdeki futbolcunun emeklisine rastlamak mümkün değildir.

Vergi tabanını genişletmeye çalışan idarenin kendisiyle çeliştiği sporculara karşı olan bu korumacı politika karşısında sadece ülkemiz sporcuları değil yabancı sporcular da kayıtsız kalmamıştır. Nitekim en üst liglerdeki yabancı sporcu sayısındaki artış son yıllarda hissedilir boyuta ulaşmıştır. Örneğin futbol Süper Liginde mücadele eden takımlarda oynayan yabancı futbolcular 2016-2017 sezonu itibariyle toplam futbolcu sayısının \% 51,8' ini oluşturmaktadır. Hatta dünyanın çeşitli ülkelerinden spor hayatlarının sonuna gelmiş ünlü sporcular düşük vergi yükü nedeniyle yüksek transfer bedelleri ödenerek ülkemize getirilmiştir. Buna karşılık ülkemizin dünya çapındaki sportif faaliyetlerdeki başarısı aynı oranda artmamıştır. Hatta uluslararası arenada takım olarak mücadele eden takımlarımızın oyuncularının büyük bir kısmı yabancı, bireysel branşlarda katılıp madalya alanların çoğu ise devşirmedir. Görüldüğü üzere mevcut vergileme teşvik etme ve korumanın çok ötesine geçmiş bir kesime özel kayırmacı hal almıştır. Yabancı oyuncu ve antrenör sayısındaki artış da düşünüldüğünde milli kaynakların teşvik adı altında ülke dışına aktarılması gibi bir trajikomik bir durumla da karşı karşıya kalınmaktadır. Hakkaniyetli yapıya bürünebilmesi ve diğer mükellefler üzerindeki olumsuz etkilerinin hafifletilmesi için sporcuların vergilendirilmesine yönelik düzenlemelerin az kazananından az, çok kazananından çok vergi alınmasını sağlayacak şekilde yeniden ele alınması kaçınılmazdır. Özellikle 888.800 .000 milyon $€$ gibi çok yüksek bir piyasa değerine ulaşmış futbol süper liginde futbol oynayan sporcuların mutlaka gerçek gelir düzeylerinin tespit edilerek beyanname vermek suretiyle vergilendirilmeleri sağlanmalıdır.

\section{2. Ücretlerde Tevkif Suretiyle Vergilendirme ve Yıllık Beyan Sınırının Değerlendirilmesi}

Vergi adaleti kavramı bir yönüyle genel adalet kavramında olduğu gibi kişiler arasındaki eşitliğe dayanır. Bu eşitlik doktrine ve Anayasamıza göre mali güçlerine göre eşitliktir. Mali gücü eşit olanların eşit vergi, mali gücü farklı olanların farklı vergi ödemesini içeren bir vergi sisteminin adil olacağı kabul edilir. Başka bir ifadeyle vergilemede mali güce bağlı farklılaşmaya izin verilir (Şenyüz, 2014: 87).

Vergilendirmede adalet ilkesi açısından tevkif suretiyle vergilendirme değerlendirildiğinde, iki farklı durum ortaya çıkar. Illk durum tam mükelleflerin kendi aralarında gerçekleşirken diğer durum tam mükellef ile dar mükellef arasında gerçekleşir. Örneğin iki ayrı işverenden ücret geliri elde eden iki ayrı tam mükellefin vergisel yükümlülükleri aşağıdaki tabloda verilmiştir. 
Tablo 4: Tam Mükellef íki Ayrı İşverenden Ücret Geliri Elde Eden İşçilerin Vergi Yükü

\begin{tabular}{|c|c|c|c|}
\hline \multicolumn{2}{|c|}{$\begin{array}{l}\text { Gerçek usulde vergilendirilen ve tam mükellef iki ayrı } \\
\text { işverenden ücret geliri elde eden29 }\end{array}$} & 1. işçi & 2. İşçi \\
\hline \multicolumn{2}{|l|}{ 1. işveren } & $50.000 \mathrm{TL}$ & $50.000 \mathrm{TL}$ \\
\hline & & \multicolumn{2}{|c|}{$100 \mathrm{TL}$} \\
\hline \multicolumn{2}{|l|}{ 2. işveren } & $29.950 \mathrm{TL}$ & $30.050 \mathrm{TL}$ \\
\hline \multirow{2}{*}{ Kaynakta kesilen gelir vergisi } & 1. işv. & $10.750 \mathrm{TL}$ & $10.750 \mathrm{TL}$ \\
\hline & 2. işv. & $5.340 \mathrm{TL}$ & $5.363,5 \mathrm{TL}$ \\
\hline \multicolumn{2}{|c|}{$\begin{array}{l}\text { Yillik Gelir Vergisi Beyannamesi } \\
\text { (G.V.K. 86. maddeye göre) }\end{array}$} & Beyanname verilmez & $\begin{array}{l}\text { Beyanname verilmes } \\
\text { zorunludur. }\end{array}$ \\
\hline \multicolumn{2}{|c|}{ Beyannamede hesaplanan vergi } & - & $18.863,5 \mathrm{TL}$ \\
\hline \multicolumn{2}{|l|}{ Mahsup edilecek gelir vergisi } & - & $16.113,5 \mathrm{TL}$ \\
\hline \multicolumn{2}{|l|}{ Ödenecek gelir vergisi } & - & $2.750 \mathrm{TL}$ \\
\hline \multicolumn{2}{|l|}{ Ödenen toplam vergi } & $16.090 \mathrm{TL}$ & $18.863,5 \mathrm{TL}$ \\
\hline \multicolumn{2}{|c|}{ Vergi yükü (Ödenen vergi/Toplam gelir) } & $\% 20,12$ & $\% 23,56$ \\
\hline \multicolumn{2}{|l|}{ Vergi yükü farkı } & \multicolumn{2}{|c|}{$\% 3,44$} \\
\hline
\end{tabular}

Kaynak: G.V.K. hükümlerine göre tarafımızdan hazırlanmıştır.

Tablo 4'de açıkça görüldüğü üzere bazı durumlarda kişinin gelirlerindeki çok küçük bir artış $(100 / 79.950=0,00125)$ üzerindeki vergi yükünü çok ciddi oranda $(3,44 / 20,12=\% 17,1)$ arttırabilmektedir. İlk iş̧̧inin vergi yükünün diğer işçiye göre daha düşük oranda gerçekleşmesinin sebebi tevkif suretiyle vergilendirmedir. Tevkif suretiyle vergilendirildiği ve beyan sınırı olan (2017 takvim yılı için $30.000 \mathrm{TL}$ ) aşmadığı için ikinci işverenden elde edilen ücret geliri birinci işverenden elde edilen ücret geliri ile toplanmamış dolayısıyla artan oranlı gelir vergisi tarifesine göre vergi hesaplanmamıştır. Başka bir ifadeyle kişinin mali gücü artmasına rağmen yine tarifenin ilk diliminden tevkifat yapılmış olması nedeniyle ücret geliri elde eden iki kişi üzerinde farklı vergi yükleri oluşmuştur. Mali gücü 100 lira gibi oldukça küçük tutarda fazla olan ve gelir vergisi beyannamesi veren işçi \% 3,44 oranında daha fazla bir vergi yüküyle karşı karşıya kalmıştır. Yine beyannameye ilişkin olarak ödemek durumunda kalacağı damga vergisi veya beyanname vermeyi unuttuğunda muhatap olacağı cezalar bu yükü daha da hissedilir duruma getirmektedir.

Birden fazla işverenden alınan ücretin kanuni sınırı geçmesi ve beyanı halinde yıl içinde tevkif edilen vergiler hesaplanan vergiden mahsup edilecektir, ancak kanuni sınırın altında kalması halinde her bir işverenden alınan ücret için yapılan vergileme nihai olacaktır. Bu durumda vergi adaleti açısından sorun, artan oranlı vergi tarifesinin tam olarak işlememesidir. Çünkü birinciden sonraki işverenden kanuni sınırın altında

\footnotetext{
${ }^{29}$ Konu sadece vergi kanunları açısından dikkate alınmış olup sgk kesintileri ve diğer tüm hususlar anlaşılabilir olması nedeniyle ihmal edilmiştir.
} 
gelir elde edilmesi halinde vergilendirme tevkifat usulüne göre yapılacak, yani farklı işverenden alınan ücretler bir araya toplanamayacak, dolayısıyla artan oranlılık tam olarak uygulanamayacaktır.

Birden fazla işverenden ücret alınması halinde birinci işverenin hangisi olduğu ücretliler tarafından serbestçe belirlenebilmektedir. Bu nedenle unutulmamalıdır ki, bazı mükellefler yıllık beyannameyi "vergi planlamasının bir aracı olarak" kullanabilmektedirler. Şöyle ki, tek işverenden alınan ve tevkif suretiyle vergilendirilen ücretler tutarı ne olursa olsun beyan edilmeyecektir. Dolayısıyla beyan edilmeyen ücretler için G.V.K.'nun 89. maddesinde yer alan indirimlerden yararlanılamayacaktır. Ancak ücretli G.V.K.'nun 89. maddesinde yar alan indirim konusu yapılabilecek giderlerden birini yaptığında (örneğin eğitim ve sağlık harcamaları) bu giderleri indirim konusu yapabilmek için yıllık beyanname ile ücret gelirlerini bildirmeyi tercih edebilecektir.

Tevkif suretiyle vergilendirmenin karşımıza çıkardığı diğer bir durum da tam mükellef ile dar mükellef karşılaştırıldığında gerçekleşmektedir. Tevkif suretiyle vergilendirilmiş diğer kazanç ve iradı bulunan dar mükellefiyete tabi kişiler yıllık beyannameyle bu gelirlerini beyan etmezken aynı gelire sahip tam mükellefiyete tabi kişiler istisna haddini aşan kısmı beyan edip artan oranlı gelir vergisi tarifesine göre hesaplanan vergiyi ödemek durumundadırlar. Görüleceği üzere aynı mali güce sahip dar mükellefin vergi yükü sabitken, tam mükellefin vergi yükü artan oranlı vergi tarifesinin en üst dilimi olan \% 35' e kadar çıkabilmektedir.

Tevkif suretiyle vergilendirme, gelirin toplanması ilkesinin bozulmasına yol açmakta dolayısıyla da kişilerin gerçek vergi ödeme güçlerinin tespit edilmesini engellemektedir. Görüldüğü üzere üniter vergi yapısını bozan mevzuat hükümleriyle; gelirin toplanmasını esneten ve bunun sonucunda toplama dışı bırakılan gelirlerle, az kazanandan az, çok kazanandan çok vergi alınmasını gerekli kılan vergi adaletinden uzaklaşılmasına zemin hazırlanmıştır (Coşkun Karadağ, 2014: 221).

Bunun yanında ilk başta stopaj yoluyla vergilendirilen ücretliler, yıllık beyan ile vergilendirilen ücretlilerden farklı olarak ellerine henüz geçmemiş gelirin vergisini ödemektedirler. Bu durum stopaj usulüne tabi ücretlilerin beyan esasına tabi mükelleflere oranla mülkiyet haklarına daha erken müdahale edildiği anlamına gelmektedir (Başaran Yavaşlar, 2012: 11).

\section{3. Ücretlerin Vergilendirilmesinin İndirilebilecek Giderler Açısından Değerlendirilmesi}

Mali gücü gayrisafi gelir değil safi gelir temsil etmektedir. Bu nedenle gelirin elde edilmesiyle bağlantılı giderlerin gayrisafi gelirden indirilmesi gerekir ki bu verginin mali güçle orantılı olması ilkesinin bir alt ilkesi olan objektif safilik ilkesinin bir gereğidir (Başaran Yavaşlar, 2012: 7). Ücretliler gayrisafi gelirden safi gelire ulaşmak amacıyla G.V.K.'nun 63., 31., 32., $89^{30}$. maddelerinde sayılan indirimler yapabileceklerdir. Matrahın tespiti konusunda vergi adaleti açısından sorun, diğer gelir unsurlarında

\footnotetext{
${ }^{30}$ Yıllık beyanname verilmesi halinde yararlanılabilecektir.
} 
gayrisafi gelirden safi gelire ulaşmada yapılabilecek indirimlerin bir kısmından ücretlilerin yararlanamamasından ortaya çıkmaktadır. Şöyle ki örneğin bir serbest meslek erbabı G.V.K.'nun 68. maddesinde sayılan mesleki giderleri gayrisafi gelirinden (hasılat) indirim konusu yapabilmektedir. Örneğin mesleki kazancın elde edilmesi ve idamesi için yapılan genel giderler ile seyahat ve ikamet giderleri safi hasılatın tespitinde indirim konusu yapılabilmektedir. Ancak ücretliler için böyle bir imkan söz konusu değildir. Vergi hukuku açısından mükelleflerin mali güçlerinin eşit olup olmadığı karşılaştırılırken, mali güçlerinin eşit kurallara göre ölçülmesi gerekir. Başka bir ifadeyle gayrisafi gelirden safi gelire ulaşmada kullanılan kuralların ve indirimine izin verilen giderlerin tüm gelir unsurları itibariyle aynı ya da benzer kapsamda olması gerekmektedir. Ancak ücretliler ile serbest meslek erbapları açısından durum değerlendirildiğinde bir ücretli ile serbest meslek erbabının mali gücü aynı kurallarla ölçülmemektedir. Bu durum mali güç ilkesine aykırılık teşkil eder (Başaran Yavaşlar, 2012: 8).

\subsection{Muafiyet ve İstisnaların Değerlendirilmesi}

Anayasamızın 73/1. maddesine göre herkes kamu giderlerini karşılamak üzere mali gücüne göre vergi ödemekle yükümlüdür. Anayasanın bu hükmünden mali gücü olan herkesin vergi ödemesi gerektiği anlaşılmaktadır. Ancak kimi vergi konuları ya da mükellef grupları sosyal ve ekonomik amaçlarla ya da teşvik amacıyla vergi dışı bırakılmıştır. Vergiyi doğuran olay gerçekleşmesine rağmen kimi mükellefler ya da mükellef grupları vergi dışı bırakılabilirken (muafiyet), yine aynı şekilde vergi konuları vergi dışı bırakılabilmektedir (istisna).

Ücretliler açısından muafiyet ve istisna hükümleri G.V.K.'nun 15., 16., 23., 24., 25., 26., 27., 28., 29. maddelerinde düzenlenmektedir. Her ne sebeple olursa olsun ücret niteliğindeki gelirlerin bazıların ya da ücret geliri elde eden kişilerin vergi dışı bırakılması gelir grupları arasında vergi eşitliğini bozmasının yanında, vergi matrahının aşınmasına, vergi gelirlerinin azalmasına neden olmaktadır (Bulutoğlu, 1976: 140). Bazı vergi konularının ya da kişilerin vergi adaleti kaygısıyla vergi dışı bırakıldıkları açıktır. Örneğin; emekli, maluliyet, dul ve yetim aylıkları, engellilik, hastalık ve işsizlik sebepleriyle verilen tazminat ve yapılan yardımlar, muhtaç olanlara belli bir süre için veya hayat kaydıyla yapılan yardımlar, hizmet erbabına ödenen çocuk zamları vb. (Bulutoğlu, 1976: 140-141).

Vergi adaleti gayesiyle bir vergi konusunun ya da kişilerin vergi dışı bırakılması anlaşılabilir bir durumdur. Ancak bazı haller vardır ki bunların hangi amaçla vergi dışı bırakıldıkları belirsizdir. Örneğin spor yarışmalarını yöneten hakemlerin ücretleri gelir vergisinde istisna edilmiştir. Türkiye Futbol Federasyonu hakemleri üç farklı kategoriye ayırmış ve her bir kategori için farklı ücretler belirlemiştir. Buna göre birinci kategoride yer alan hakemler $20.000 \mathrm{TL}$, ikinci kategoride yer alan hakemler $17.000 \mathrm{TL}$, üçüncü kategoride yer alan hakemler ise $13.000 \mathrm{TL}$ aylık ücret geliri elde etmektedir. Aylık ücretler dışında maç başına da Süper Lig'de maç yöneten hakemler $5.750 \mathrm{TL}$, 1. Lig'de maç yöneten hakemler ise 3.000 TL gelir elde etmektedirler. Aylık ücret ve maç başı ücret yanında hakemler görev aldıkları yerlerin uzaklığına göre 850 TL'ye varan harcırahlar elde edebilmektedirler. Bu yönüyle bakıldığında birinci kategoride yer alan 
hakemlerin aylık geliri 45.000 TL'yi bulabilmektedir. Asgari ücretlilerin artan oranlı vergi tarifesine tabi tutulduğu ülkemizde hakemlerin ücretlerinin vergiden istisna edilmesi vergi adaletine ters düşmektedir.

İstisna müessesesine ilişkin diğer bir sorun da kapıcıların ücretlerinde karşımıza çıkmaktadır. G.V.K.'nun 23/6 maddesine göre özel fertler tarafından evlerde, bahçelerde, apartmanlarda ve ticaret mahalli olmayan diğer yerlerde çalıştırılan kapıcıların aldığı ücretler vergiden istisna edilmiştir. Buna karşılık ticaret mahalli olan yerlerde çalışan kapıcıların ücretleri vergiye tabi tutulmaktadır. Gerek işhanında gerekse de apartman gibi ticari mahiyette olmayan yerlerde çalışan ve görevleri tamamıyla aynı olmasına karşıık farklı vergilendirilen iki kapıcının durumu eşitlik ilkesine aykırıdır. Mahiyetleri itibariyle aynı sayılabilecek iş için vergisel farklılığı gerektirecek gerekçeler yok denecek kadar düşük seviyede olmasına rağmen işhanında çalışan kapıcıların ücretlerinin vergiye tabi tutulması aynı zamanda dağıtıcı adaletin anahtarı konumundaki mali güç ilkesine de aykırılık oluşturur (Şenyüz, 2014: 88). Bilindiği üzere apartman yönetimi ile kapıcılar arasında hizmet akdinin varlığı nedeniyle apartman yönetimleri de işveren sıfatını kazanmaktadırlar (Tosuner \& Bay, 2014: 99). İş ve hizmet karşıı̆̆ının da ancak ücret ile ödenebileceği İ̧̧ Kanununda açıkça düzenlenmiştir. Dolayısıyla ticari vasfı olmayan yerde çalışan kapıcının elde ettiği ücretin, mükellefiyetinin tespit ve izlenmesindeki güçlük nedeniyle vergiden istisna edilmesi buna karşılık söz konusu güçlüğün ticari mahallerde çalışan kapıcılar bakımından ortadan kalktığından hareketle gelir vergisine tabi tutulmasının -teknolojik gelişmelerin ve vergi idaresinin buna uyumundaki başarısı da düşünüldüğünde- sosyal nedenlerin arkasına saklanarak açıklanması mümkün değildir. Günden güne artan fonksiyonları ve bunların finansmanı için Devletin daha kolay vergilendirilebilen alanlara/kişilere yönelmesi diğerleri için istisna öngörmesini haklı kılmaz. Bir ticarethane kapıcısının ücreti istisnadan yararlanamazken, özel hizmetlerdeki kapıcı veya ücreti çok daha yüksek olan dadıların ücretlerinin vergi dışı kalması (Özbalcı, 2007: 194) veya daha ağır işlerde çalışan bazı ücretlilere muaflık tanınmaması (Öncel vd., 2012: 43) eşitlik ilkesine ters düşmektedir.

\subsection{Diğer Durumlar}

Ayırma kuramı gereğince sermaye gelirleri emek gelirlerine nazaran daha ağır vergi tarifesine tabi tutulmak suretiyle vergilendirilmelidir (Bulutoğlu, 1976: 135). Ayırma kuramı gereğince ücretlilerin vergilendirilmesi bakımından farklı vergi tarifesi uygulamak yerine diğer gelir unsurlarıyla aynı tarifeye göre vergi hesaplanması bunun yanında tarifenin üçüncü diliminden itibaren farklılaştırma yapılması ve çok az sayıda ücretlinin -genellikle diğer ücretlilere göre yüksek ücret geliri elde edenlerin- bu imkandan yararlanması adil değildir. Öğretinin genel kuralı olarak emek gelirlerinin sermaye kazançları karşısında vergilendirilirken korunması gerekir. Oysa mevcut düzenlemeler beyanname vermek zorunda olmayan ücretlileri beyanname veren mükelleflere karşı korumamaktadır. Hatta ücret geliri elde edenleri kendi içinde bile adil vergilendirmeyerek geliri az olana doğru vergi yükünün ağırlaşmasına neden olmaktadır. 
Örneğin basit usulde vergilendirilen bir ayakkabı tamircisinin yanında çalışan biriyle yine aynı usule tabi minibüs veya taksi işletmesinde şoför olarak çalışan kişinin diğer ücret gelirleri tutar olarak birbirlerinden farklı olmasına rağmen mevzuat gereği aynı vergiyi ödemek durumunda kalmaktadırlar. Bu durum mali gücü eşit olanların aynı, mali gücü farklı olanların farklı şekilde vergilendirilmesi anlamına gelen mali güç ilkesine, dolayısıyla vergi adaletine ters düşmektedir.

\section{Sonuç}

Anayasamızın 73. maddesinde de belirtildiği gibi vergilendirmede mali güç ilkesi geçerlidir. Bu nedenle gayrisafi gelir mali gücü temsil etmediğinden gayrisafi gelirden gelirin elde edilmesiyle ilgili giderlerin indirilmesi ve safi gelire ulaşılması gerekir. Nitekim gerçek ücretlerde safi gelire ulaşmak G.V.K.'nun 63/1 maddesinde dört bent halinde sayılan giderlerin gayrisafi gelirden indirim konusu yapılması gerekmektedir. Bunun yanında aynı Kanun'un 31. maddesinde engellilik derecesine göre birtakım indirimler söz konusudur. Bu indirimlerin de aylık tutarlar itibariyle gayrisafi ücretten indirilmesi gerekmektedir. Ancak bu indirimler gelirin elde edilmesi için yapılan giderleri tam anlamıyla karşılamamaktadır. Diğer ücretliler ise G.V.K.'nun 64/1 maddesinde beş bent halinde sayılmıştır. Buna göre kazançları basit usulde tespit edilen ticaret erbabının yanında çalışanlar, özel hizmetlerde çalışan şoförler, özel inşaatlarda çalışan iş̧̧iler, gayrimenkul sermaye iradı sahibi yanında çalışanlar, gerçek ücretlerinin tespitine imkan olmaması sebebiyle, Danıştay'ın müspet mütalaasıyla, Maliye bakanlığınca bu kapsama alınanlar diğer ücretli olarak değerlendirilmektedir.

Türk gelir vergisinde beyana dayalı vergilendirme esas iken ücret gelirlerinin vergilendirilmesinde beyan esasından farklı olarak stopaj usulü tercih edilmiştir. Ücret gelirlerinin vergilendirilmesinde stopaj usulü nihai vergilendirme niteliğindedir. Ancak bazı durumlarda (G.V.K. 95, 86/1-b) ücret gelirlerinin beyanname ile bildirilmesi gerekmektedir.

Ücret gelirlerinin vergilendirilmesinde farklı vergilendirme usullerinin belirlenmesi vergi adaleti açısından birtakım sorunların ortaya çıkmasına neden olmaktadır. Mali güç ilkesinin bir gereği olarak eşit mali durumda olanların eşit bir şekilde, farklı mali durumda olanların ise faklı şekilde vergilendirilmesi gereği ücret gelirlerinin vergilendirilmesinde bazı kanuni düzenlemeler nedeniyle mümkün olmamaktadır. Örneğin en üst liglerdeki sporculara yapılan ödemelerden \% 15 oranında tevkifat yapılmakta iken, asgari ücretlinin artan oranlı tarifeye tabi olması vergi adaletini zedelemektedir. Bunun yanında yıllık beyanname ile gelirlerini beyan edenlerin G.V.K.'nun 89. maddesinde yer alan indirimlerden yararlanmalarına rağmen, stopaj usulünde vergilendirilenlerin -beyanname vermediklerinden- bu indirimlerin bazılarından yararlanamamaktadır. Bu uygulama da vergi adaletine ters düşmektedir. Bir ücretlinin birden fazla işverenden ücret geliri elde etmesi mümkündür. Birden fazla işverenden alınmakla birlikte, birinci işverenden sonraki işverenlerden alınan ücretler toplamı G.V.K.'nun 103. maddesinin ikinci gelir diliminde yer alan tutarı (2017 yılı için $30.000 \mathrm{TL}$ ) aşmıyorsa tevkif edilen vergi bu gelirler için nihai niteliktedir. Kanuni sınırı aşması halinde ise tamamı beyan edilmelidir. Birden fazla işverenden alınan ücretin kanuni sınırı geçmesi ve beyanı halinde yıl içinde tevkif edilen vergiler hesaplanan 
vergiden mahsup edilecektir, ancak kanuni sınırın altında kalması halinde her bir işverenden alınan ücret için yapılan vergileme nihai olacaktır. Birinciden sonraki işverenden kanuni sınırın altında gelir elde edilmesi halinde vergilendirme tevkifat usulüne göre yapılacak, yani farklı işverenden alınan ücretler biraraya toplanamayacak, dolayısıyla artan oranlılık tam olarak uygulanamayacaktır.

Mükellefler arasında kanuni düzeyde yapılacak farklı uygulamalar mali güç ilkesi dikkate alınarak yapılmalıdır. Örneğin apartmalarda çalışan kapıcılar gelir vergisinden muafken, işhanında çalışan kapıcıların ücretlerinin vergiye tabi olması mali güç ilkesine dolayısıyla vergi adaletine ters düşmektedir. Bunun yanında diğer ücretliler sınıfında yer alan mükelleflerin vergilendirilmesinde de vergi adaletine aykırı uygulamalar bulunmaktadır. Örneğin basit usulde vergilendirilen bir minübüs işletmesinde şöför olarak çalışan bir kişinin elde ettiği ücret geliri ile yine aynı şekilde vergilendirilen bir berberin yanında çalıştırdığı işçiye ödediği ücret tutarı farklı olmasına rağmen aynı tutarda götürü olarak tespit edilen matrah üzerinden vergilendirilmektedir. Dolayısıyla mali güçleri bakımından farklı durumda bulunan kişiler aynı tutarda vergi ödemektir. Bu durum gerek Anayasaya gerekse de az kazanandan az, çok kazanandan çok vergi alınmasını ifade eden adalet ilkesine aykırı bir durumdur. Yine asgari geçim indirimi uygulamasından sadece gerçek usulde vergilendirilen ücretlilerin yararlanması da vergi adaletine aykırıdır.

\section{Kaynakça}

Akdoğan, A. (2011). Kamu Maliyesi, 14. Baskı, Ankara, Gazi Kitabevi.

Akdoğan, A. \& Kırbaş S. (1986). Açıklamalı Maliye ve Vergi Terimleri Sözlüğü, Ankara, Birlik Yayıncılık.

Arıkan, Z. (2005). "Türk Vergi Sisteminin Genel Değerlendirilmesi ve Çözüm Önerileri", Vergi Sorunları Dergisi, Sayı: 199, ss. 151-166.

Armağan, R. (2006). "Gelir Vergisinde Ücret Gelirlerinin Vergilendirilmesi ve SosyoEkonomik Etkileri Üzerine Bir Değerlendirme", Süleyman Demirel Üniversitesi iktisadi ve Idari Bilimler Fakültesi Dergisi, Cilt: 11, Sayı: 2, ss. 323-347, http://dergipark.gov.tr/download/article-file/194873, (28.04.2017).

Başaran Yavaşlar, F. (2012). "Bir Adaletsizlik Örneği: Ücret Gelirlerinin Vergilendirilmesi", Fasikül Dergisi, Sayı: 30, ss. 6-12, http://www.fundabasaran.net/wp-content/uploads/2014/12/Bir-Adaletsizlik\%C3\%96rne\%C4\%9Fi-\%C3\%9Ccret-Gelirlerinin-Vergilendirilmesi.pdf, (27.04.2017).

Beyanname Düzenleme Kılavuzu. (2013). Maliye Hesap Uzmanları Derneği, Cilt 1, İstanbul, Acar Basım ve Cilt San.Tic. Aş.

Biyan, Ö. \& Yılmaz G. (2012). "Ücretlerin Vergilendirilmesine İlişkin Karşılaştırmalı Bir Öneri: Beyanname Yükümlülüğü", Maliye Dergisi, Sayı: 162, ss. 184-218. 
Bulutoğlu, K. (1976). Türk Vergi Sistemi, 5. Baskı, İstanbul, Fakülte Matbaası.

Cingi, S. (2010). "Ünlü Yatırımcılar At Koşturuyor”, Radikal Gazetesi, 5 Aralık 2010, http://www.radikal.com.tr/ekonomi/unlu-yatirimcilar-at-kosturuyor-1031443/, (05.03.2017).

Coşkun Karadağ, N. (2014), "Finansal Araçların Vergilendirilmesi, İhtiyari Beyan ve Sağladığı Vergi Avantajları", Cumhuriyet Üniversitesi iktisadi ve Idari Bilimler Dergisi, Cilt: 15, Sayı: 2, S. 205-224, http://dergi.cumhuriyet.edu.tr/cumuiibf/article/view/5000016519/500006577 0 (26.04.2017).

Deyneli, F. (2010). Türkiye'de Adalet Ekonomisinin Karşılaştırmalı Analizi, Maliye Bakanlığı Strateji Geliştirme Başkanlığı Yayın No: 2010/405, Ümit Ofset Matbaacılık, Ankara.

Erdem, T. (2013). "Vergi illkelerinin KDV'si ve ÖTV'si Üzerinden Vergi Adaleti Arayışı”, Vergi Sorunları Dergisi, Sayı: 297, ss. 44-54.

Erginay, A. (1995). Vergi Hukuku, 15. Baskı, Ankara, Savaş Yayınları.

Gelir İdaresi Başkanlığı. (2017a). Ücret Geliri Elde Edenler İçin Vergi Rehberi, Mükellef Hizmetleri Daire Başkanlığı Yayın No: 246, Şubat 2017, Ankara.

Gelir İdaresi Başkanlığı. (2017b). Engelliler İçin Vergi Rehberi, Mükellef Hizmetleri Daire Başkanlığı Yayın No: 250, Nisan 2017, Ankara.

Kaneti, S. (1986/1987). Vergi Hukuku, İstanbul, Özdem Kardeşler Matbaası.

Karakoç, Y. (2013). “Anayasal Vergilendirme İlkeleri Üzerine Bir Değerlendirme”, Dokuz Eylül Üniversitesi Hukuk Fakültesi Dergisi, Cilt: 15, ss. 1259-1308, http://hukuk.deu.edu.tr/dosyalar/dergiler/dergimiz-15-ozel/3-kamu/4yusufkarakoc.pdf (27.3.2017).

Kızılot, Ş., Şenyüz, D., Taş, M. \& Dönmez, R. (2007). Vergi Hukuku, 2. Baskı, Ankara, Yaklaşım yayıncılık

Laufenburger, H. (1954). Histoire De L'impôt (Que sais-je), Paris, Presses Universitaires De France, (Çev.) Ragıp Hanyal (1964), Vergiler ve Tarihi, Ankara, Kardeş Matbaası.

Maliye Bakanlığı. (2016). Vergi Harcamaları Raporu 2016, Gelir Politikaları genel Müdürlüğü,

Ankara, http://www.gep.gov.tr/Web/GenelMudurlukDokuman.aspx?prmts=1594, (19.04.2017).

Munyar, V. (2011). "Yarış Deyip Geçmeyin, Bir Atı Çiftleştirmek 500 Bin Lirayı Buluyor", Hürriyet Gazetesi, 25.02.2011, http://www.hurriyet.com.tr/yaris-deyipgecmeyin-bir-ati-ciftlestirmek-500-bin-lirayi-buluyor-17115309, (05.03.2017).

Mutlu, A. (2009). Tanzimattan Günümüze Türkiye'de Vergileme Zihniyetinin Gelişimi, Maliye Bakanlığı Strateji Geliştirme Başkanlığı Yayın No: 2009/390, Ankara, Ümit Ofset Matbaacılık. 
Neumark, F. (1975). Vergi Politikası, İstanbul, Filiz Kitabevi.

Öncel, M., Kumrulu, A. \& Çağan N. (2012). Vergi Hukuku, 21. Bası, Ankara, Turhan Kitabevi.

Öz, E. \& Akçay F. (2013). "Futbolcular Özelinde Sporcuların Vergilendirilmesi”, Vergi Sorunları, Sayı: 300, ss. 35-54.

Özbalcı, Y. (2007). Gelir Vergisi Kanunu Yorum ve Açıklamaları, Ankara, Oluş Yayıncılık.

Pehlivan, O. (2011). Vergi Hukuku: Genel ilkeler ve Türk Vergi Sistemi, Trabzon, Murathan Yayınevi.

Saban, N. (2006). Vergi Hukuku, 4. Bası, İstanbul, Beta Basım Yayım Dağıtım.

Sheffrin, S.M. (1993). "What Does The Public Believe About Tax Fairness?", National Tax Journal, Vol. 46 (3), New Directions In Tax Policy, pp. 301-308, http://www.jstor.org/stable/41789022, (23.03.2017).

Şenyüz, D. (2007). Türk Vergi Sistemi, 13. Baskı, Ankara, Yaklaşım Yayıncılık.

Şenyüz, D., Yüce, M., Gerçek A. (2011). Türk Vergi Sistemi Dersleri, 4. Baskı, Bursa, Ekin Basım Yayın Dağıtım.

Şenyüz, D. (2014). "Hukuk Devleti Perspektifinden Adil Vergileme ve Vergi Afları", Tesam Akademi Dergisi, Cilt: 1, Sayı: 2, ss. 81-96, http://www.tesamakademi.com/download/makale2014-2/4.pdf, (20.05.2017).

Topuzkanamış, E. (2013). "Yeniden Paylaşım, Vergilendirme ve Adalet", Dokuz Eylül Üniversitesi Hukuk Fakültesi Dergisi, 14(1), ss. 103-131, http://hukuk.deu.edu.tr/dosyalar/dergiler/dergimiz-14 1/engintopuzkanamis.pdf, (13.03.2017).

Tosuner, M. \& Arıkan Z. (2017). Türk Vergi Sistemi, 22. Bası, İzmir, Kanyılmaz Matbaası.

Tosuner, M. \& Bay H. (2014). “Apartman Yönetimi ve Vergisel Boyutu”, Prof. Dr. Fevzi Devrim'e Armağan, 1. Baskı, Dokuz Eylül Üniversitesi İktisadi ve İdari Bilimler Fakültesi Maliye Bölümü Yayın No: 09.1600.0000.000/DR.014.094.753, İzmir, Dokuz Eylül Üniversitesi Matbaası.

Tuncer, S. (2012). "Vergi Hukuku Açısından İşyeri", Maliye Araştırma Merkezi Konferansları, Prof. Dr. Memduh Yaşa'ya Armağan, Sayı: 34, ss. 192-208.

Türk, İ. (1992). Kamu Maliyesi, 1. Baskı, Ankara, Turhan Kitabevi.

Uluatam, Ö. (1991). Kamu Maliyesi, 4. Baskı, Ankara, Savaş Yayınları.

Yaltı Soydan, B. (1998). "Vergi Adaleti Kavramında Soyuttan Somuta: Türk Anayasa Mahkemesi Kararlarını Eşitlik, Özgürlük ve Sosyal Devlet Kavramları İle Okumak", Vergi Sorunları Dergisi, Sayı: 119, ss. 98-118.

Yereli, A.B. \& Ata A.Y. (2011), "Vergi Adaletine Ulaşma Yöntemleri Çerçevesinde Fayda İlkesinin Teorik Açıdan Değerlendirilmesi", Maliye Dergisi, S: 161, ss. 21-32, https://dergiler.sgb.gov.tr/calismalar/maliye dergisi/yayinlar/md/161/002.pdf, (19.03.2017). 